\title{
Biocompatibility of mannan nanogel-safe interaction with plasma proteins
}

\author{
Sílvia A. Ferreira ${ }^{\mathrm{a}, *}$, Cecilia Oslakovic ${ }^{\mathrm{b}}$, Risto Cukalevski ${ }^{\mathrm{c}}$, Birgitta Frohm ${ }^{\mathrm{c}}$, Björn Dahlbäck ${ }^{\mathrm{b}}$, Sara Linse ${ }^{\mathrm{c}}$, \\ Francisco M. Gama ${ }^{a}$, Tommy Cedervall ${ }^{\mathrm{c}}$ \\ a Institute for Biotechnology and Bioengineering, Centre for Biological Engineering, University of Minho, Campus Gualtar, $4710-057$ Braga, Portugal \\ ${ }^{\mathrm{b}}$ Department of Laboratory Medicine, Division of Clinical Chemistry, Lund University, Skåne University Hospital, SE-20502, Malmö, Sweden \\ c Department of Biochemistry and Structural Biology, Centre for Molecular Protein Science, Chemical Centre, Lund University, PO Box 124, SE-221 00, Lund, Sweden
}

\section{A R T I C L E I N F O}

\section{Article history:}

Received 24 November 2011

Received in revised form 12 April 2012

Accepted 16 April 2012

Available online 24 April 2012

\section{Keywords:}

Mannan nanogel

Protein corona

Coagulation

Fibrillation

Biosafety

Biocompatibility

\begin{abstract}
A B S T R A C T
Background: Self-assembled mannan nanogels are designed to provide a therapeutic or vaccine delivery platform based on the bioactive properties of mannan to target mannose receptor expressed on the surface of antigen-presenting cells, combined with the performance of nanogels as carriers of biologically active agents. Methods: Proteins in the corona around mannan nanogel formed in human plasma were identified by mass spectrometry after size exclusion chromatography or centrifugation followed by sodium dodecyl sulfate polyacrylamide gel electrophoresis. Structural changes and time dependent binding of human apolipoprotein A-I (apoA-I) and human serum albumin (HSA) to mannan nanogel were studied using intrinsic tryptophan fluorescence and circular dichroism spectroscopy. The mannan nanogel effect on blood coagulation and fibrillation of Alzheimer's disease-associated amyloid $\beta$ peptide and hemodialysis-associated amyloidosis $\beta 2$ microglobulin was evaluated using thrombin generation assay or thioflavin T fluorescence assay, respectively. Results: The protein corona around mannan nanogel is formed through a slow process, is quite specific comprising apolipoproteins B-100, A-I and E and HSA, evolves over time, and the equilibrium is reached after hours to days. Structural changes and time dependent binding of apoA-I and HSA to mannan nanogel are minor. The mannan nanogel does not affect blood coagulation and retards the fibril formation.

Conclusions: Mannan nanogel has a high biosafety and biocompatibility, which is mandatory for nanomaterials to be used in biomedical applications.

General Significance: Our research provides a molecular approach to evaluate the safety aspects of nanomaterials, which is of general concern in society and science.
\end{abstract}

(c) 2012 Elsevier B.V. All rights reserved.

\section{Introduction}

Nanometer-sized polymeric hydrogels, i.e. nanogels, combine favorable and exceptional properties, such as flexible size in the nanometer range, tunable chemical and physical structures, large surface areas for multivalent conjugation, high water content, and biocompatibility $[1,2]$. Nanogels represent a promising class of delivery devices for biologically active agents because of their loading capacity, their stability, as well as their responsiveness to environmental factors [1].

A self-assembled mannan nanogel has been designed and characterized in our group as a potential multifunctional nanosized device for biomedical applications [3]. The mannan nanogel is spherical and polydisperse with a mean hydrodynamic diameter between 50 and $140 \mathrm{~nm}$, and has a slightly negative surface charge [3].

\footnotetext{
* Corresponding author. Tel.: + 351253604427 ; fax: + 351253604429.

E-mail addresses: silviarmferreira@gmail.com (SA.. Ferreira), cecilia.oslakovic@gmail.com (C. Oslakovic), risto.cukalevski@biochemistry.lu.se (R. Cukalevski), birgitta.frohm@biochemistry.lu.se (B. Frohm), bjorn.dahlback@med.lu.se (B. Dahlbäck), sara.linse@gmail.com (S. Linse), fmgama@deb.uminho.pt (FM.. Gama), tcedervall@yahoo.com (T. Cedervall).
}

Mannose receptor, expressed in the surface of antigen-presenting cells [4-7], was previously shown to take part in host defense, providing a linkage between innate and adaptive immunity [7-10]. The choice of mannan as the main component of the nanogel aims to take advantage of the association of the bioactive properties of mannan with the performance of nanogels as carriers of biologically active agents. The mannan nanogel is thus suggested as a possible tool for vaccine formulations, acting as an adjuvant suitable to induce a protective and long-lasting immune response, or as a targeted therapeutic delivery system to be used for the treatment of macrophage associated pathologies.

Nanoparticles, including nanogels, will interact with proteins in a biological environment creating an outer layer around the particle known as the protein corona $[11,12]$. The proteins are the most studied substances in the corona but it can include other biomolecules, for example lipids [13]. The composition and surface chemistry of a specific nanoparticle will dictate the extent and specificity of protein binding [12]. Surface charge, hydrophobicity, particle size, morphology, shape and surface curvature of nanoparticles affect what proteins bind to the nanoparticle $[11,12,14-20]$. The composition of the protein corona on a given nanoparticle, at a given time, will depend on the protein concentrations in the physiological fluid and the on- and 
off-rates for each protein [14]. Thus the protein corona, the biological identity of the nanoparticle, will change with time [20-24] and with environmental changes [24,25], for example, when nanoparticles travel from blood to inside cells [25]. The protein corona will be important for the biocompatibility and biosafety. Proteins on the nanoparticle surface can interact with blood proteins and cell receptors, and consequently affect uptake and intracellular fate [24,26-32], biodistribution of the nanomaterials throughout the body, toxicity and/ or efficacy [14,15,33-35].

When proteins bind to nanoparticles a structural change in the protein often occurs $[16,36]$. It has been proposed that these structural changes, in addition to the protein composition in the corona, may lead to changed biological functions and consequently be important for evaluating the biosafety of nanoparticles [14,30,36]. Recent reports describe how changes in the corona can mediate the biological impact of the nanoparticles. Fibrinogen bound to poly(acrylic acid)-coated gold nanoparticles undergo a structural change that can facilitate interaction and activation of MAC- 1 receptor pathway on macrophage-like cells and subsequent inflammation response [37]. Enzyme activity can be enhanced and stabilized over time when bound to nanoparticles [38]. The opposite is also true as trypsin immobilized on silica and polystyrene nanospheres [39], or lysozyme and $\alpha$-chymotrypsin [40] bound to gold nanoparticles experienced a large structural change, and the enzymes lost their activity. On most studied spherical particles, apolipoproteins are identified in the corona formed in human blood plasma [11]. They suffered a structural change after binding to polystyrene particles [41]. Apolipoproteins are central in the fat metabolism and uptake of apolipoprotein binding polystyrene particles through a feeding web could cause severe metabolic and behavioral disturbances in fish [42].

Proteins important for the initiation and regulation in the coagulation cascade have been identified in the corona from polystyrene [20], citrate-capped gold [24], and silica nanoparticles [25]. Recent results in our laboratory have shown that amine-modified polystyrene nanoparticles inhibited coagulation by specific interactions with two coagulation factors and that in opposite carboxyl-modified polystyrene nanoparticles activated the coagulation [43]. It is highly relevant to test particle destined to circulate in the body for its effect on the coagulation cascade because disorders of coagulation can lead to an increased risk of bleeding (hemorrhage) or obstructive clotting (thrombosis). The fluorometric thrombin generation assay is proposed as a good method to evaluate the procoagulant activity of nanomaterials in human plasma and has been used to study the procoagulation effects caused by several nanoparticles [44].

Protein aggregation can lead to major disturbances of cellular processes and is associated with several diseases. Proteins may under certain conditions and as a function of time give up their natively folded state and form amyloid fibrils $[45,46]$. Human amyloid diseases involve self-assembly of soluble proteins into large insoluble fibrils through nucleation-dependent assembly, often via the formation of oligomeric structures that possess toxic properties $[47,48]$. The fibrillation of amyloid proteins and peptides as Alzheimer's disease-associated amyloid $\beta$ peptide $(A \beta(M 1-40))$ found in brain lesions and hemodialysis-associated amyloidosis $\beta 2$ microglobulin $(\beta 2 \mathrm{~m})$ are well studied. Nanomaterials [46], such as nanogel formed by self-aggregation of cholesterol-bearing pullulan with molecular chaperone-like activity [49] and $N$-isopropylacrylamide: $N$-tert-butylacrylacrylamide (NIPAM: BAM) nanoparticles [50], have been linked to $A \beta$ fibrillation retardation. In contrast, NIPAM:BAM nanoparticles caused acceleration of $\beta 2 \mathrm{~m}$ fibrillation [51]. Also, at constant $A \beta(M 1-40)$ concentration, the fibrillation process was accelerated by amino-modified polystyrene nanoparticles at low concentration, while at high nanoparticle concentration, the fibrillation process was retarded [52].

In the present work, the protein corona around mannan nanogel in human plasma was characterized to evaluate its biosafety and biocompatibility from a molecular perspective. Proteins in the corona were identified by mass spectrometry after gel filtration using size exclusion chromatography (SEC) or centrifugation followed by sodium dodecyl sulfate polyacrylamide gel electrophoresis (SDS-PAGE). Time dependence and structural changes of human apolipoprotein A-I (apoA-I) and human serum albumin (HSA) binding to mannan nanogel were studied using intrinsic tryptophan fluorescence and circular dichroism (CD) spectroscopy. The mannan nanogel effect on blood coagulation was evaluated by fluorometric thrombin generation assay. The role of mannan nanogel in protein fibrillation was evaluated by continuous thioflavin $\mathrm{T}$ (ThT) fluorescence assay using both $A \beta(M 1-40)$ and $\beta 2 \mathrm{~m}$.

\section{Material and methods}

\subsection{Materials}

Mannan-VMA-SC ${ }_{16}$ (VMA: vinyl methacrylate, $\mathrm{SC}_{16}$ : hydrophobic alkyl chain) was synthesized as described previously [3] with 31 acrylate groups ( $\mathrm{DS}_{\mathrm{VMA}} 31 \%$ ) and 20 alkyl chains ( $\left.\mathrm{DS}_{\mathrm{C} 16} 20 \%\right)$ per 100 mannose residues. Resultant amphiphilic mannan is named as $\mathrm{MVC}_{16}-31-20$. With $\mathrm{DS}_{\mathrm{C} 16} / \mathrm{DS}_{\mathrm{VMA}}$ equal to $65 \%$, it has critical aggregation concentration $(\mathrm{cac})$ or critical micelle concentration $(\mathrm{cmc})$ equal to $0.01 \mathrm{mg} / \mathrm{mL}$ [3]. Human donors' plasma from lipidemic patients was obtained from the local hospital blood bank and preserved in aliquots at $-80^{\circ} \mathrm{C}$. Before each experiment aliquots were defrosted and centrifuged for $2 \mathrm{~min}$ at $14,927 \mathrm{~g}$ (Biofuge 13 , Heraeus) and immediately used after rejecting the top lipid layer. ApoA-I was purified from human plasma as previously described [53]. HSA (Sigma, A3782, fatty acid free, 99\% pure) was purified from dimer and contaminating proteins using gel filtration on a $200 \times 3.4 \mathrm{~cm}$ Sephadex G50 column in $50 \mathrm{mM}$ ammonium acetate buffer, pH 6.5. Fractions containing HSA monomer were pooled, lyophilized and desalted by gel filtration on a G25 Sephadex superfine column in Millipore water. ApoA-I and HSA stock solutions $(10 \mathrm{mg} / \mathrm{mL})$ were dialyzed for 5 days against frequently changed phosphate buffered saline pH 7.5 (PBS) at $4{ }^{\circ} \mathrm{C}$ using twice boiled in distilled water regenerated cellulose tubular membranes, with 6000-8000 nominal MWCO, obtained from Membrane Filtration Products. Phospholipids were obtained from Avanti Polar Lipids, Inc. (Alabaster, AL, USA). Recombinant tissue factor was obtained from Dade Innovin (Marburg, Germany). The thrombin fluorogenic substrate I-1140 (Z-Gly-Gly-Arg-7-amino-4-methylcoumarin $\cdot \mathrm{HCl}$ ) was purchased from Bachem (Bubendorf, Switzerland). A $\beta(M 1-40)$ was expressed in Escherichia coli and purified as previously described [54]. $\beta 2 \mathrm{~m}$ was expressed in E. coli and purified as previously described [51]. Organic and inorganic reagents of laboratory grade were purchased from Sigma-Aldrich and used without any further purification, unless otherwise stated. Water was purified with a Milli-Q system (Millipore Corporation).

\subsection{Mannan nanogel preparation}

Colloidal dispersions of amphiphilic mannan were prepared stirring the lyophilized $\mathrm{MVC}_{16}-31-20$ in PBS, for $3-5$ days at $50{ }^{\circ} \mathrm{C}$, followed by filtration (Orange; pore size $0.22 \mu \mathrm{m}$ ). The nanogel formation was confirmed by dynamic light scattering (DLS; Malvern Zetasizer NANO ZS-Malvern Instruments Limited, UK) as previously described [3]. The colloidal dispersion of nanogel $(2 \mathrm{mg} / \mathrm{mL})$ showed $z$-average equal to $154.1 \pm 5.625 \mathrm{~nm}$ and polydispersity index (PdI) of $0.229 \pm 0.007$.

\subsection{Gel filtration of mannan nanogel and plasma proteins}

Plasma $(250 \mu \mathrm{L})$ was incubated with mannan nanogel $(800 \mu \mathrm{L}$ at $2 \mathrm{mg} / \mathrm{mL})$ or with PBS $\left(800 \mu \mathrm{L}\right.$; control) stirring for $24 \mathrm{~h}$ at $37^{\circ} \mathrm{C}$. Samples were separated by SEC on a $100 \times 1 \mathrm{~cm}$ Sephacryl $1000 \mathrm{col}-$ umn. The absorbance of all fractions was recorded at $280 \mathrm{~nm}$ in UV- 
1800 spectrophotometer (SHIMADZU UV). Individual fractions from 22 to 37 pooled from four different experiments were precipitated with trichloroacetic acid $10 \%$ and frozen at $-20^{\circ} \mathrm{C}$. Samples were centrifuged $15 \mathrm{~min}$ at 14,927g (Heraeus Kendro Biofuge 13), and the pellet was washed with ice cold acetone. Pellets were resuspended in $5 \mu \mathrm{L}$ of PBS, and proteins were desorbed from the nanogel by adding $10 \mu \mathrm{L}$ of sodium dodecyl sulfate (SDS) loading buffer and incubated for $5 \mathrm{~min}$ at $95^{\circ} \mathrm{C}$. Samples were separated by SDS-PAGE, with resolving gel $15 \%$ and stacking gel $4 \%$. Each gel run included one lane of a molecular weight ladder standard, PageRuler Prestained Protein Ladder (Fermentas). Gels were Coomassie stained. All fractions resultant of SEC separation of nanogel alone had similar absorbance to that obtained with the PBS at $280 \mathrm{~nm}$.

\subsection{Identification of corona proteins using centrifugation and mass spectrometry}

Colloidal dispersions of mannan nanogel in PBS (100 $\mu \mathrm{L} ; 0,0.1$, $0.25,0.5,0.75,1$ or $2 \mathrm{mg} / \mathrm{mL}$ ) were incubated stirring with plasma or PBS $(100 \mu \mathrm{L})$ for 1 and $24 \mathrm{~h}$ at $37^{\circ} \mathrm{C}$. Colloidal dispersions of mannan nanogel in PBS $(100 \mu \mathrm{L} ; 2 \mathrm{mg} / \mathrm{mL})$ were incubated stirring with increasing amount of plasma $(50 \mu \mathrm{L}, 100 \mu \mathrm{L}, 200 \mu \mathrm{L}, 400 \mu \mathrm{L}$ or $800 \mu \mathrm{L}$; in a fixed final volume), for 1 and $24 \mathrm{~h}$ at $37^{\circ} \mathrm{C}$. Samples were centrifuged $15 \mathrm{~min}$ at 19,873g (Heraeus Kendro Biofuge 15), and the pellet was washed twice with $500 \mu \mathrm{L}$ PBS changing the vial after each washing step. Samples were separated by SDS-PAGE and Coomassie blue stained as described above. Each experiment was performed twice. Gels were preserved in $1 \%$ acetic acid in water at $4{ }^{\circ} \mathrm{C}$ for mass spectrometry. Bands were excised from the gel, reduced, alkylated, and digested with trypsin (Sequencing Grade Promega, Madison, WI), and the resulting peptide mixtures were analyzed by MALDI-TOF mass spectrometry using a 4700 Proteomics Analyzer (Applied Biosystems, MA) mass spectrometer in positive reflector mode. Both MS and tandem MS (MS/MS) spectra were analyzed by Matrix Science Mascot software to identify tryptic peptide sequences.

\subsection{Circular dichroism spectroscopy}

ApoA-I or HSA were incubated stirring at $37^{\circ} \mathrm{C}$ in the absence and in the presence of the mannan nanogel at various concentrations in PBS. CD measurements were carried out using a JASCO J-815 spectropolarimeter (JASCO, Easton, MD) with a Peltier type thermostated cell holder. Far-UV CD spectra $(190-260 \mathrm{~nm})$ were recorded at $37^{\circ} \mathrm{C}$ in continuous mode with a scan rate of $50 \mathrm{~nm} / \mathrm{min}$ and a digital integration time of $8 \mathrm{~s}$ using $0.1 \mathrm{~cm}$ quartz cuvettes with a Teflon stopper. Three spectra were accumulated and averaged for each sample. The average spectra for a blank (colloidal dispersion of mannan nanogel - Fig. S1A in Supplementary data - or buffer) were subtracted from the spectrum of each protein sample. The conformation of protein in the absence and in the presence of the nanogel was estimated from CD spectra. This experiment was performed at least twice.

\subsection{Intrinsic tryptophan fluorescence}

ApoA-I or HSA were incubated stirring at $37^{\circ} \mathrm{C}$ in the absence and the presence of the mannan nanogel at various concentrations in PBS. Fluorescence measurements were performed on a luminescence spectrometer LS 50B (PerkinElmer) with a cuvette holder thermostated at $37^{\circ} \mathrm{C}$. Fluorescence emission spectra $(310-460 \mathrm{~nm})$ were recorded at an excitation wavelength of $290 \mathrm{~nm}$ with a scan rate of $100 \mathrm{~nm} / \mathrm{min}$. Three spectra were accumulated and averaged for each sample. Reported average spectra are those after the subtraction of the spectrum for a blank (colloidal dispersion of mannan nanogel - Fig. S1B in Supplementary data - or buffer) from the spectrum of each protein sample. Also fluorescence emission spectra of a colloidal dispersion of mannan nanogel $(0.6 \mathrm{mg} / \mathrm{mL})$ with ApoA-I or HSA $(0.1 \mathrm{mg} / \mathrm{mL})$ were recorded over time at $37^{\circ} \mathrm{C}$. These experiments were performed at least twice.

\subsection{Thrombin generation assay}

The amount of thrombin formed in plasma/mannan nanogel samples were monitored using the thrombin generation assay as previously described [55] with the following modifications. Natural phospholipids, 20-20-60 phosphatidylserine-phosphatidylethanolaminephosphatidylcholine (PS-PE-PC), were mixed and prepared. Citrate platelet poor plasma $(40 \mu \mathrm{L})$ was preincubated with $40 \mu \mathrm{L}$ of $4-(2-$ hydroxyethyl)-1-piperazineethanesulfonic acid (HEPES) buffered saline (HBS, $10 \mathrm{mM}$ HEPES, $150 \mathrm{mM} \mathrm{NaCl}$, pH 7.4) or mannan nanogel (final concentration of $1 \mathrm{mg} / \mathrm{mL}$ ) at $37^{\circ} \mathrm{C}$ for $15 \mathrm{~min}$. Fluorogenic substrate (Z-Gly-Gly-Arg-7-amino-4-methylcoumarin $\cdot \mathrm{HCl} ; 20 \mu \mathrm{L}$ ) was added to samples and coagulation was initiated with $20 \mu \mathrm{L}$ of phospholipids/tissue factor/ $\mathrm{CaCl}_{2}$ mixture in a final volume of $120 \mu \mathrm{L}$. All reagents were diluted in HBSBSA (HBS buffer supplemented with $5 \mathrm{mg}$ / $\mathrm{mL}$ of bovine serum albumin (BSA)), and final concentrations were approximately $1.17 \mathrm{pM}$ tissue factor, $4.2 \mu \mathrm{M}$ phospholipids, $300 \mu \mathrm{M}$ fluorogenic substrate and $16 \mathrm{mM} \mathrm{CaCl}_{2}$. Fluorescence measurements over time were taken in black flat bottom 96-well plates (Nalge Nunc International, Rochester, NY, USA) in a plate Tecan Infinite 200 fluorometer equipped with a $360 \mathrm{~nm}$ excitation/460 nm emission filter set (Mölndal, Sweden) and Magellan software (Gröedig, Austria).

\subsection{Thioflavin T fluorescence assay}

Peptide $A \beta(M 1-40)$ samples in $20 \mathrm{mM}$ sodium phosphate buffer $\mathrm{pH} 7.4,200 \mu \mathrm{M}$ ethylenediaminetetraacetic acid (EDTA), $0.02 \% \mathrm{NaN}_{3}$ or protein $\beta 2 \mathrm{~m}$ samples in $20 \mathrm{mM}$ sodium phosphate buffer $\mathrm{pH} 2.5$, $50 \mathrm{mM} \mathrm{NaCl}, 0.02 \% \mathrm{NaN}_{3}$, were pipetted into wells of a 96 -well halfarea plate of black polystyrene with a clear bottom and polyethylene glycol coating (Corning 3881), $50 \mu \mathrm{L}$ per well, which contained either $50 \mu \mathrm{L}$ of respective buffer or $50 \mu \mathrm{L}$ of mannan nanogel in respective buffer, resulting in final $10 \mu \mathrm{M} A \beta(\mathrm{M} 1-40)$ or $40 \mu \mathrm{M} \beta 2 \mathrm{~m}$ concentrations and final nanogel concentrations between $0.001 \mathrm{mg} / \mathrm{mL}$ and $0.9 \mathrm{mg} / \mathrm{mL}$. All samples were supplemented with $20 \mu \mathrm{M}$ ThT. Plate was sealed with a plastic film (Corning 3095). The nanogel size was not affected in the buffers used as confirmed by DLS. Fibrillation of $A \beta(M 1-40)$ and of $\beta 2 \mathrm{~m}$ at $37{ }^{\circ} \mathrm{C}$ was monitored by the temporal development of ThT binding in the absence and in the presence of mannan nanogel at $0.001-0.9 \mathrm{mg} / \mathrm{mL}$.

The experiment was initiated by placing the 96 -well plate at $37{ }^{\circ} \mathrm{C}$ and shaking at $100 \mathrm{rpm}$ in a plate reader (Fluostar Omega, BMGLabtech, Offenburg, Germany). The ThT fluorescence was measured through the bottom of the plate every 6 min (with excitation filter $440 \mathrm{~nm}$ and emission filter $480 \mathrm{~nm}$ ) with continuous shaking at $100 \mathrm{rpm}$ between reads. The ThT fluorescence was followed for two different 96-well plates (one plate with 8 samples for $A \beta(M 1-40)$ and $\beta 2 \mathrm{~m}$ in pentaplicate, and another plate with 8 samples for $A \beta(M 1-40)$ and $\beta 2 \mathrm{~m}$ in hexaplicate) yielding in total 11 kinetic traces per sample. Controls that ran with only nanogel with ThT showed that the nanogel did not interfere with the assay. The dye selectively binds to amyloid fibrils with an accompanying increase in fluorescence intensity [56,57]. Interaction of amyloid fibrils and protofibrils with ThT causes a red shift in its excitation spectrum [58], and ThT fluorescence is therefore a measure of fibrillogenesis. The kinetics aggregation data have a sigmoidal appearance and exhibits characteristics of a typical nucleation-dependent polymerization and growth process. The time course of fibrillogenesis includes a lag phase during which the concentration of ThT-positive aggregates is too low to be detected followed by a rapid exponential growth (elongation) of fibrils $[59,60]$. 


\section{Results and discussion}

\subsection{Apolipoprotein corona around mannan nanogel}

Samples of mannan nanogel incubated with human plasma for $24 \mathrm{~h}$ at $37^{\circ} \mathrm{C}$ were separated by SEC. Two distinct peaks are seen in the elution profile (Fig. 1A upper panel). The major peak that elutes at fraction 71 is also found in SEC of plasma only and corresponds to the elution of unbound proteins. A minor peak elutes at around fraction 26. This peak is not seen in experiments with plasma only and likely corresponds to mannan nanogel associated with plasma proteins. In order to characterize the proteins associated with the nanogel, individual fractions 22 to 37 from four different experiments were pooled, precipitated with trichloroacetic acid and the proteins visualized by Coomassie blue after separation by SDS-PAGE (Fig. 1A middle panel). Several proteins are found in the precipitated fractions. In control experiments without mannan nanogel no proteins are found in fractions 22 to 37 (Fig. 1A lower panel), which strongly indicates that these proteins are associated and co-elute with the nanogel. The protein profile of human plasma is shown in Fig. S3 in Supplementary data, and clearly it is different from the profile of plasma proteins associated with mannan nanogel. One protein with a molecular weight around $68 \mathrm{kDa}$ is seen in all fractions when nanogel is added. This is likely to be HSA, which is the most prominent protein in plasma (about $35 \mathrm{mg} / \mathrm{mL}$ ). The high concentration of HSA means that even if it binds to the nanogel with low affinity it is likely to co-elute and continuously detach from the nanogel over the elution time.

Another common way to separate particles with bound proteins from unbound proteins is by centrifugation. The mannan nanogel was mixed with human plasma and incubated $1 \mathrm{~h}$ at $37^{\circ} \mathrm{C}$. The mixture was centrifuged, the pellets washed and bound proteins dissolved in buffer with SDS and separated by SDS-PAGE (Fig. 1B). Several proteins are co-pelleted with the nanogel indicating that they are bound to the

A

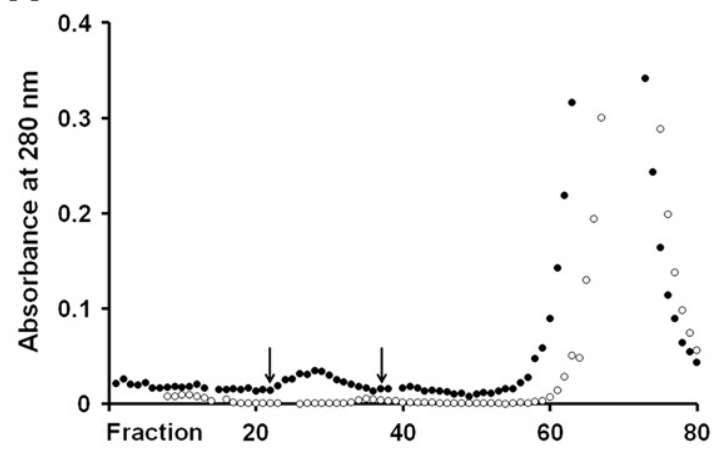

$\begin{array}{llllllll}22 & 23 & 24 & 25 & 26 & 27 & 28 & 29\end{array}$

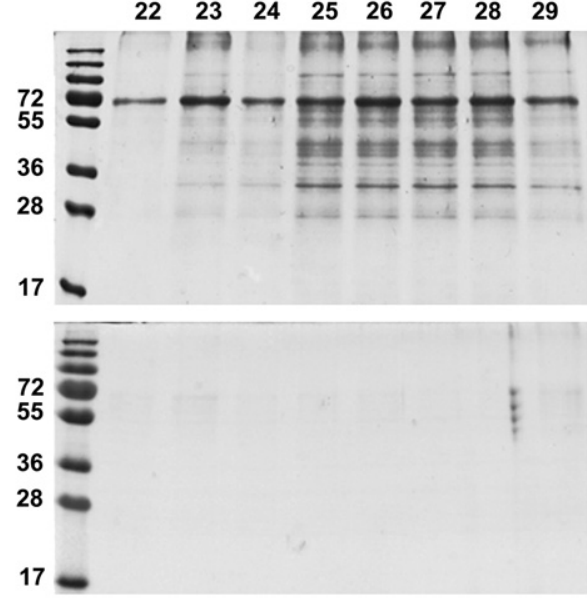

$\begin{array}{llllllll}30 & 31 & 32 & 33 & 34 & 35 & 36 & 37\end{array}$

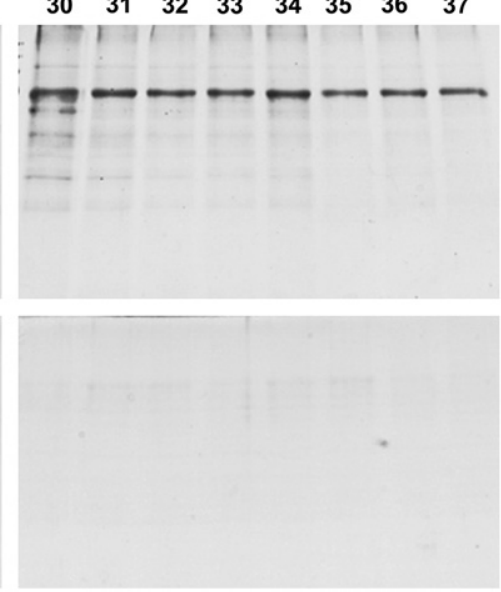

B

C

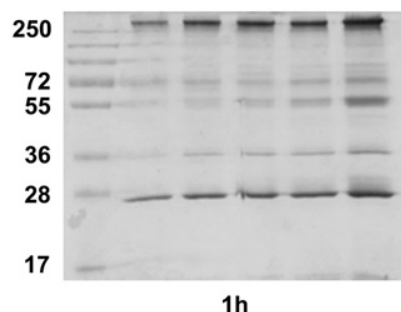

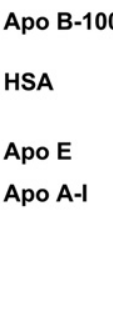

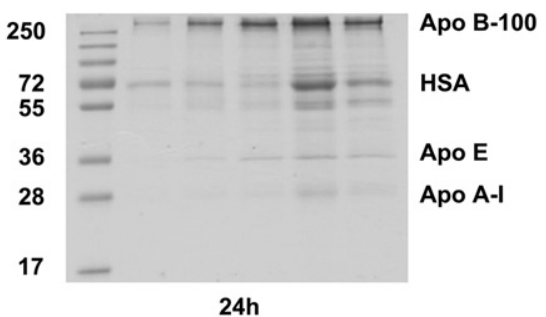

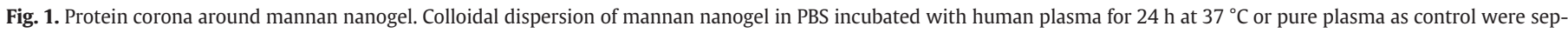

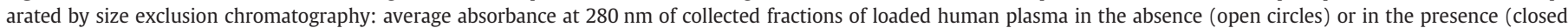

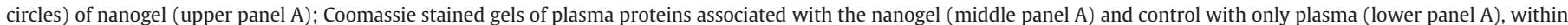

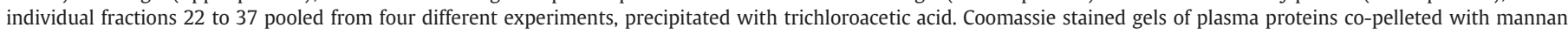

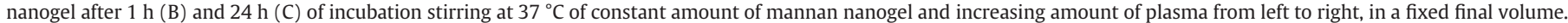


nanogel in plasma. Longer time of incubation, higher nanoparticle concentrations, or higher concentration of plasma produced larger pellets during centrifugation experiments. No pelleted proteins were seen in experiments without nanogel (data not shown). Nanogel in buffer will not pellet at the same centrifugation speed showing that the density and/or aggregation properties of the mannan nanogel are changed after plasma proteins have bound. To identify the bound proteins, the five major protein bands were cut out from a similar SDS-PAGE, the proteins digested with trypsin and the peptides subjected to mass spectrometry. The five major proteins after $1 \mathrm{~h}$ of incubation are identified as apolipoproteins B-100, A-I and E, and HSA (Fig. 1B). One major protein band with an apparent molecular weight of $55 \mathrm{kDa}$ is unidentified. This is a comparably simple protein corona. Most studied nanoparticles have a much more complex protein corona with a wide variety of proteins. One particle, the NIPAM:BAM copolymer, has a protein corona with mainly apolipoproteins, but without B-100 [11,12]. It would be interesting to compare the influence on the biocompatibility of the corona for these two materials with other nanoparticles.

A comparison of the bound proteins isolated by SEC and centrifugation, after incubation for 1 or $24 \mathrm{~h}$, shows not only several similarities but also differences. The five major proteins are present in all conditions, but the ratios between the proteins are different. In the centrifugation experiments, apolipoproteins B-100 and A-I are the dominating proteins but after $24 \mathrm{~h}$ the ratio between HSA and apolipoproteins is larger than after $1 \mathrm{~h}$ of incubation (Fig. $1 \mathrm{~B}$ and C). This change in ratios is more pronounced in SEC in which mannan nanogel also was incubated for $24 \mathrm{~h}$ in plasma before separation. In SEC experiments there is an extra major protein band around $50 \mathrm{kDa}$. This protein band also appears in centrifugation after $24 \mathrm{~h}$ of incubation but in much smaller amounts. These differences in the corona between 1 and $24 \mathrm{~h}$ indicate that the corona is formed through a slow process and that equilibrium is reached only after a long time. A time dependent corona has been observed for sodium citrate stabilized gold nanoparticles [22,24]. It was also shown that cell uptake of particles was different depending on the time particles were incubated in media before adding to the cells [61]. Consequently, time may be an important factor for how mannan nanogel interacts with the surrounding fluids and tissues after administration into the body.

\subsection{Structural consequences of apoA-I and HSA binding to mannan nanogel}

Protein binding to nanoparticles is often accompanied by a structural change in the proteins $[16,37,41,62]$. Two proteins in the corona around mannan nanogel, apoA-I and HSA were chosen for further analysis of the protein structure after binding to the nanogel. $C D$ spectroscopy was used to follow changes in the secondary structure of the proteins. The CD spectrum of apoA-I has two minima at 222 and $208 \mathrm{~nm}$, which are characteristic of the $\alpha$-helical structure (Fig. 2A). After adding mannan nanogel to apoA-I the negative signal at 222 and $208 \mathrm{~nm}$ is stronger, indicating an increase or stabilization of the $\alpha$-helical structure. Also HSA has $\alpha$-helical structure, but for HSA there are no significant changes in the structure after adding nanogel (Fig. 2C)

Intrinsic tryptophan fluorescence spectroscopy is used to follow changes in the tertiary structure of the proteins. The fluorescence spectra of apoA-I and HSA have maxima at 340 and $344 \mathrm{~nm}$, respectively (Fig. 2B and D) indicating a folded protein structure in which the tryptophan side chain is buried in a hydrophobic internal environment. Adding mannan nanogel to the apoA-I causes a decreased
A

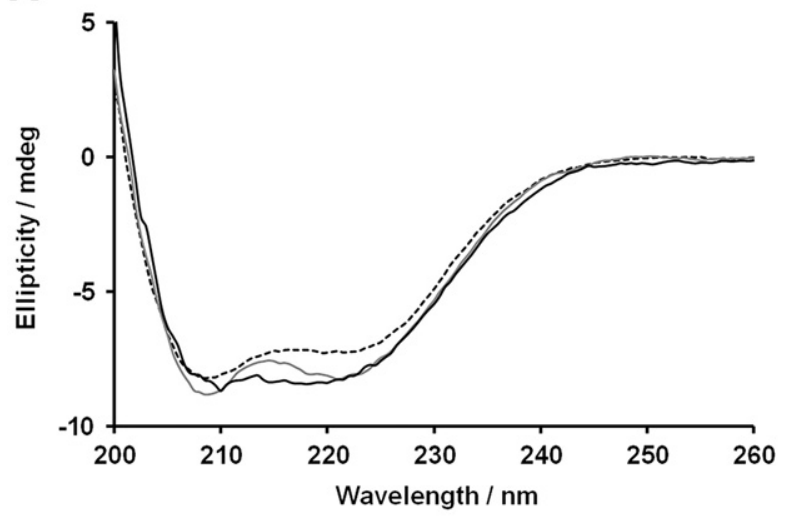

B

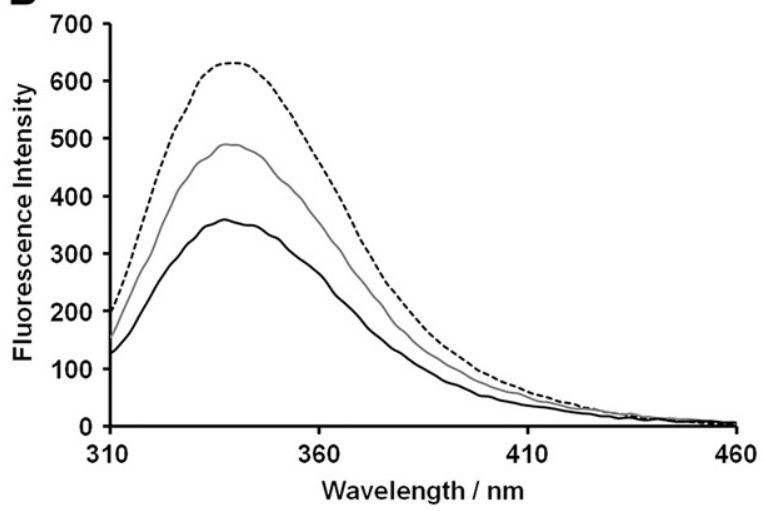

C

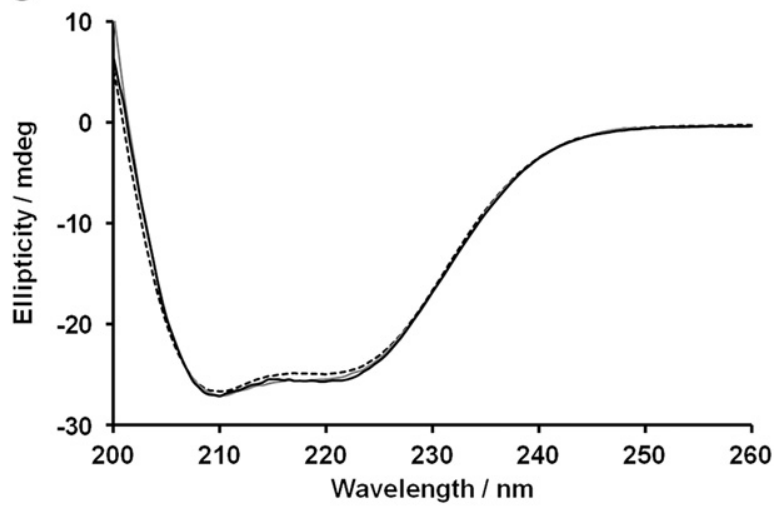

D

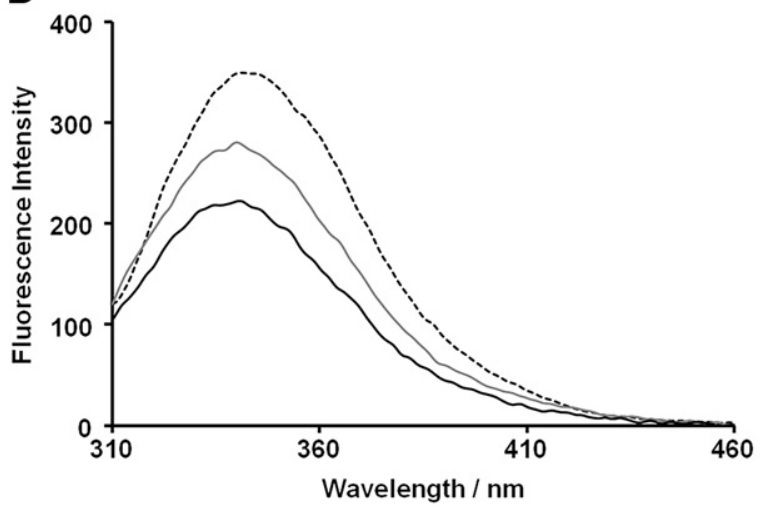

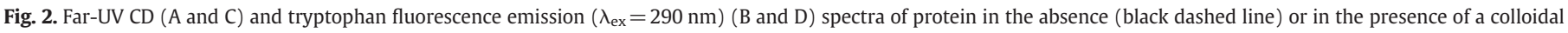

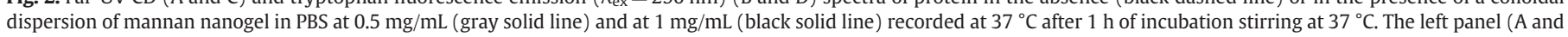
B) shows spectra recorded with apoA-I at $0.1 \mathrm{mg} / \mathrm{mL}$, and the right panel (C and D) shows spectra recorded with HSA $0.2 \mathrm{mg} / \mathrm{mL}$. 
intensity, indicating that the signal is quenched by nanogel or that the tryptophan side chain is buried in the interface between the protein and nanogel after protein binding. Adding mannan nanogel to HSA induces, in addition to the decrease in intensity, a blue shift in the wavelength maximum, indicating that the environment around the tryptophan side chains is more hydrophobic after binding to the nanogel.

ApoA-I is the main protein in high-density lipoprotein (HDL) particle and central in the lipid metabolism. A structural change in the protein altering the function of apoA-I could thereby influence the lipid metabolism in a potential harmful way. An increase of helical structure in apoA-I is also seen when it binds to phospholipids in HDL [63-65]. The structural change seen in both cases may be caused by stabilization of the protein structure normally occurring when apoA-I binds to a spherical surface.

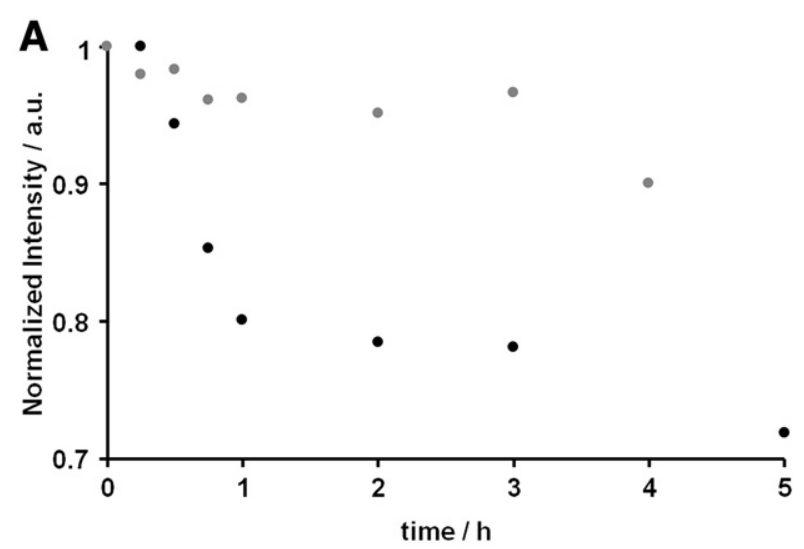

B

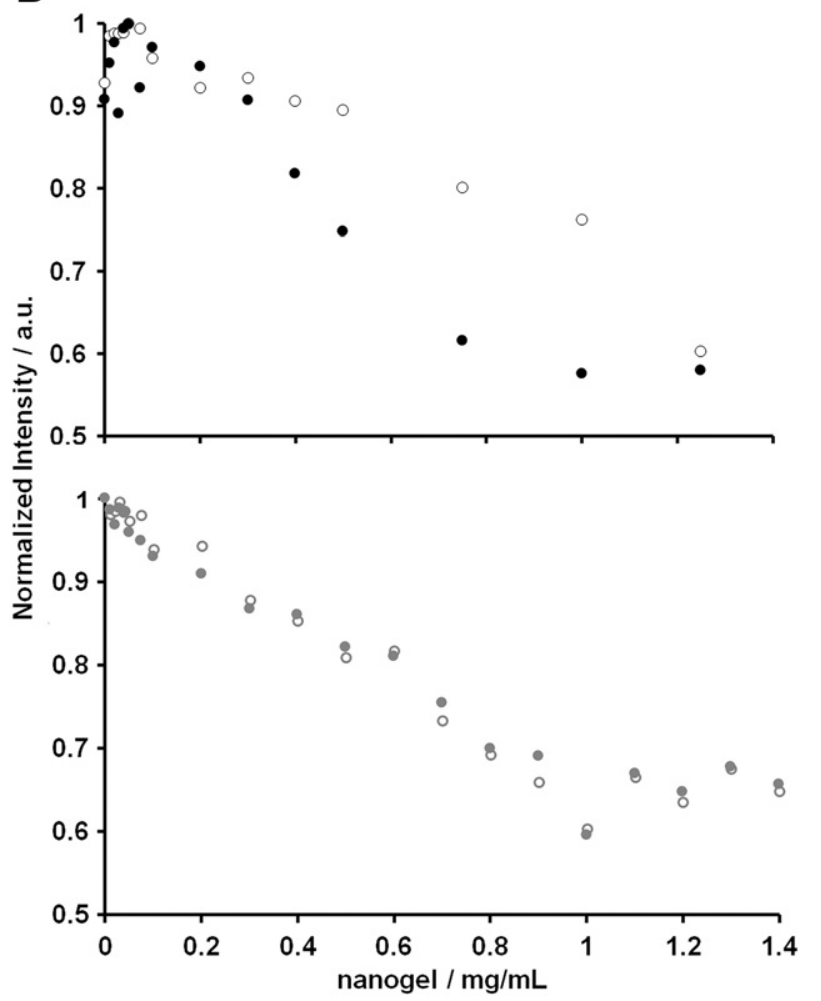

Fig. 3. Time dependent binding of apoA-I (black) and HSA (gray) at $0.1 \mathrm{mg} / \mathrm{mL}$ to mannan nanogel at $0.6 \mathrm{mg} / \mathrm{mL}$ in PBS at $37^{\circ} \mathrm{C}$. Normalized tryptophan emission intensity $\left(\lambda_{\mathrm{ex}}=290 \mathrm{~nm}\right)$ at $345 \mathrm{~nm}$ as function of time (A). Fluorescence titration of apoA-I (black) and HSA (gray) solutions at $0.1 \mathrm{mg} / \mathrm{mL}$ in the presence of colloidal dispersions of mannan nanogel at various concentrations in PBS after stirring $1 \mathrm{~h}$ (open circles) and $24 \mathrm{~h}$ (closed circles) at $37^{\circ} \mathrm{C}$. Normalized fluorescence intensity at $345 \mathrm{~nm}$ as function of mannan nanogel concentration (B).

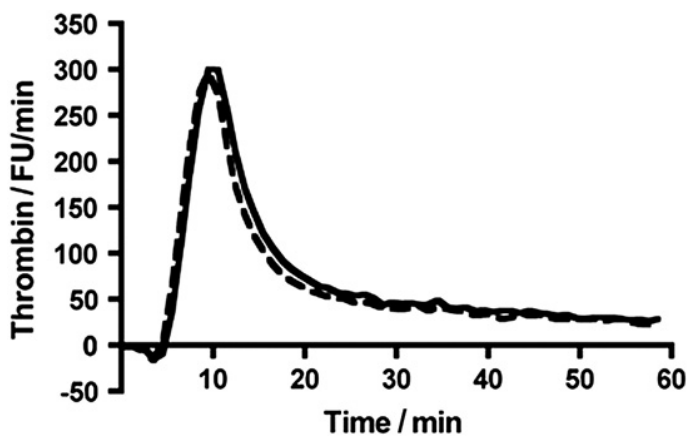

Fig. 4. The effect on thrombin generation by mannan nanogel. Plasma was incubated in the absence (solid line) or in the presence (dashed line) of a colloidal dispersion of mannan nanogel at $1 \mathrm{mg} / \mathrm{mL}$, and tested for thrombin generation using the thrombin generation assay. The first derivative, fluorescence units/min, is shown (average, $n=3)$.

\subsection{Time dependent binding between apoA-I and mannan nanogel}

The centrifugation experiments in human plasma showed that ratios between proteins in the corona change over time. In general this is expected as predicted by the Vroman effect; proteins present at high concentration in plasma will bind first but will be replaced over time by proteins with lower concentrations but higher affinity. However, for mannan nanogel also the total amount of proteins in the corona appeared to be lower after $24 \mathrm{~h}$ compared to after $1 \mathrm{~h}$. A plausible scenario is that the proteins and/or the mannan nanogel structures are changed slowly over time whereby the time to reach equilibrium will be many hours. One such scenario could be that the proteins with time enter the nanogels and interact with the hydrophobic domains inside the nanogels. To test if the proteins' structural change is time dependent, the intrinsic tryptophan fluorescence was measured after 1 and $24 \mathrm{~h}$. A clear difference in intensity is seen for apoA-I, but not for HSA after 1 and $24 \mathrm{~h}$ of incubation with nanogel (Fig. S2 in Supplementary data). To further characterize the time dependency, the intensity from the proteins in the presence of nanogel at $0.6 \mathrm{mg} / \mathrm{mL}$ was obtained at different time points (Fig. 3A). The intensity from HSA is constant while the intensity from apoA-I decreases over time. The most prominent change takes place within $1 \mathrm{~h}$, but the intensity continues to decrease for several hours indicating that the process of apoA-I binding to the nanogel is slow. The affinity of the binding is compared by measuring the intensity at $345 \mathrm{~nm}$ after $1 \mathrm{~h}$ (open circles) and $24 \mathrm{~h}$ (closed circles) for apoA-I (black circles) and HSA (gray circles) in increasing concentrations of mannan nanogel (Fig. 3B). The intensity decreases with increasing concentrations of nanogel for both apoA-I and HSA. No differences are seen between the titration curves for HSA after 1 and $24 \mathrm{~h}$, and at high concentrations of nanogel the intensity is constant indicating that all proteins are bound to the nanogel. In contrast there is a striking difference between the titration curves after 1 and $24 \mathrm{~h}$ of incubation of nanogel and apoA-I. The intensity decreases more at nanogel concentrations over $0.3 \mathrm{mg} / \mathrm{mL}$ after $24 \mathrm{~h}$ of incubation than after $1 \mathrm{~h}$, indicating that more proteins are bound to the nanogel or that a different structural change has occurred after $24 \mathrm{~h}$ of incubation. As the estimated amount of apoA-I on the particle is lower after $24 \mathrm{~h}$ than after $1 \mathrm{~h}$ of incubation (Fig. 1B) the explanation that apoA-I undergoes a slow structural change, which may involve interactions with hydrophobic domains inside the mannan nanogel, is more plausible. The stability in size of nanogel over time was tested by measuring the mean hydrodynamic diameter of the mannan nanogel in the presence and in the absence of HSA (Fig. S4 in Supplementary data). No significant changes were observed indicating that the nanogel is stable over the time frame of the measurement. The time dependent structural changes that were seen in the corona 
proteins emphasize the importance of studying the biocompatibility over time.

Attempts were made to estimate the affinity from the titration experiments. The dissociation constant $\left(K_{\mathrm{D}}\right)$ of HSA-nanogel complex is estimated to be in $\mu \mathrm{M}$ range (not shown). A similar value of $K_{\mathrm{D}}, 6 \mu \mathrm{M}$, was obtained by isothermal titration calorimetry (Fig. S5 in Supplementary data), indicating that HSA binds with low affinity to the mannan nanogel. The apoA-I data could not be fitted using Langmuir equation. Low affinity of albumin binding has been observed for other nanoparticles NIPAM:BAM copolymer, $0.83 \mu \mathrm{M}$ [66]; $20 \mathrm{~nm}$ gold, $2.5 \mu \mathrm{M}$ [62]; and polystyrene, $1.2 \mu \mathrm{M}$ [41]. The low affinity, compared to for example the higher affinity, $1 \mathrm{nM}$, of apoA-I to NIPAM:BAM copolymer [21], explains why only small amount of HSA is found on the particles although the plasma concentration is high.

\subsection{Mannan nanogel does not affect blood coagulation}

The effect on blood coagulation by mannan nanogel was tested by the thrombin generation assay. No inhibition or stimulation of the thrombin generation is seen when mannan nanogel is added to the system (Fig. 4). In another study, using the same assay, aminemodified polystyrene nanoparticles $(0.5 \mathrm{mg} / \mathrm{mL})$ inhibited the thrombin generation whereas $220 \mathrm{~nm}$ carboxyl-modified polystyrene nanoparticles $(0.5 \mathrm{mg} / \mathrm{mL})$ promoted the thrombin generation [43]. Several other nanoparticles can act as procoagulants in the same assay, for example carbon black, silicon dioxide, silicon carbide, titanium carbide and copper oxide nanoparticles [44]. As shown above the protein corona around mannan nanogel is, in contrast to most other nanoparticles studied, simple and consists mainly of apolipoproteins. For NIPAM:BAM copolymer nanoparticles, however, a similar protein corona of apolipoproteins was described [11,12]. An increase of the more hydrophilic NIPAM part leads to decreased amount of proteins bound, but that did not change the identity of the proteins $[11,12]$. To compare two different polymer particles with similar protein corona, NIPAM coated gold nanoparticles were tested by the thrombin generation assay (Fig. S6 in Supplementary data). No stimulation of the coagulation was seen. Maybe a simple corona of apolipoproteins is less prone to stimulate the coagulation and is a sign of biocompatibility from a coagulation perspective.

\subsection{Mannan nanogel retards $A \beta(M 1-40)$ and $\beta 2 m$ fibrillation}

The formation of amyloid aggregates was studied in the absence and in the presence of mannan nanogel using a continuous ThT binding assay. A significant increase in ThT fluorescence was observed over time, suggesting amyloid fibrils are formed both with and without nanogel present. However, the presence of mannan nanogel leads to a slight retardation of both $A \beta(M 1-40)$ and $\beta 2 \mathrm{~m}$ fibrillation at nanogel concentrations in the range $0.03-0.9 \mathrm{mg} / \mathrm{mL}$ where the aggregation is delayed by at most a factor of two-three (Fig. 5). An important result is that under no conditions do we see any acceleration of aggregation as has been observed for other nanoparticles $[49,50]$. Thus it appears that the nanogel acts to reduce the rate of nucleation, but the elongation rate is essentially unaffected by the presence of the nanogel. At constant $A \beta(M 1-40)$ and $\beta 2 \mathrm{~m}$ concentration, the time
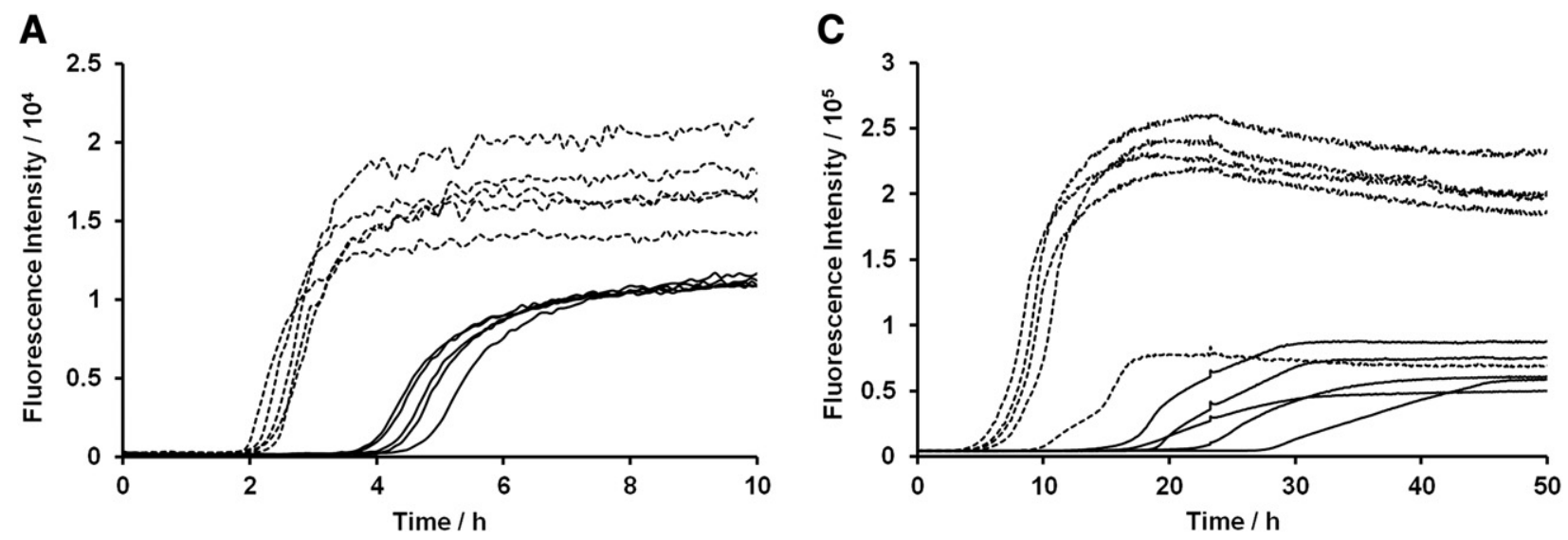

B

D
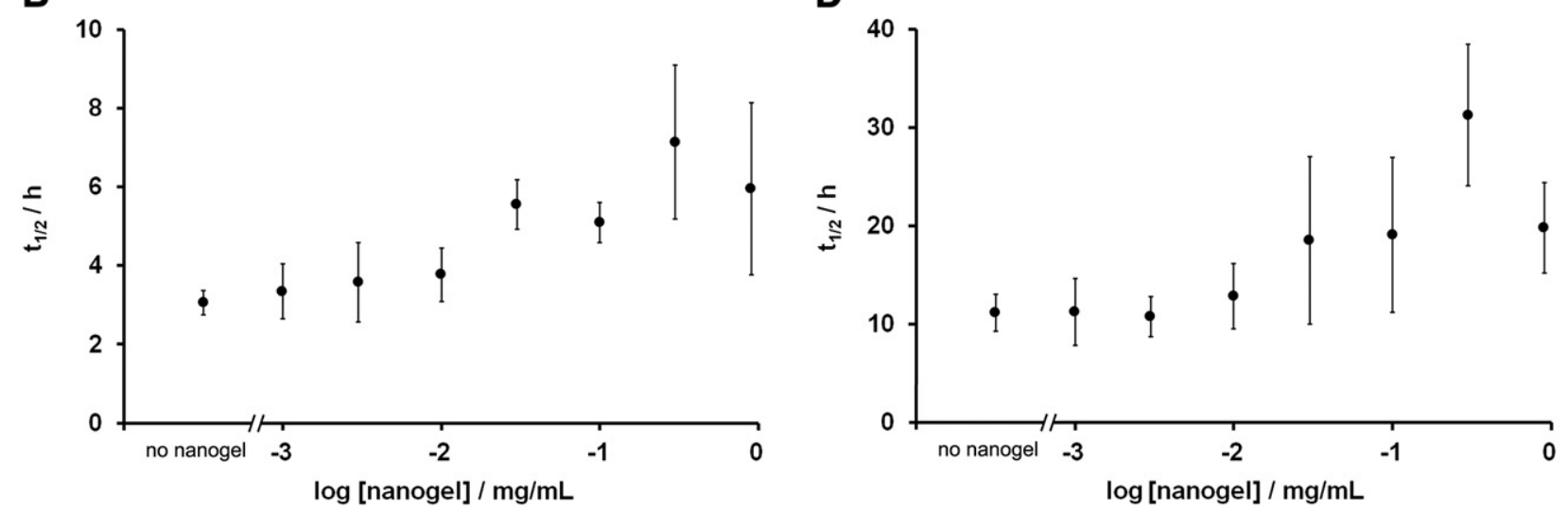

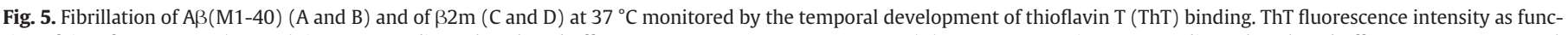

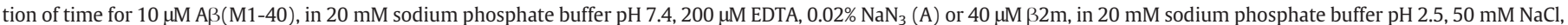

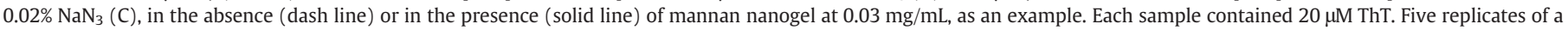

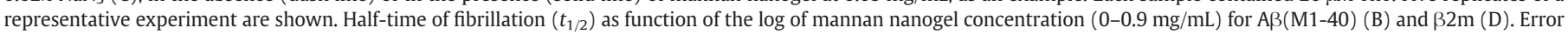
bars indicate the standard deviation of the average of 11 replicates, 5 and 6 of two independent experiments. 
required to reach half of the maximum fluorescence intensity $\left(t_{1 / 2}\right)$, increases with the increase in mannan nanogel concentration suggesting that the formation of fibrils is delayed by interaction of $A \beta(M 1-40)$ and $\beta 2 \mathrm{~m}$ with the nanogel. Moreover, the inhibitory effect is clearly concentration dependent. Addition of nanogel at a concentration $0.03 \mathrm{mg} / \mathrm{mL}$ is needed in order to see a significant effect. This is the first concentration tested above the cac or cmc equal to $0.01 \mathrm{mg} / \mathrm{mL}$, which corresponds to the self-assembly of the amphiphilic monomers of $\mathrm{MVC}_{16}-31-20$ and to the formation of the mannan nanogel.

So far studies indicate that it is the composition of nanoparticles and their surface characteristics that determine their impact on fibrillogenesis [45]. The mannan nanogel acts as artificial chaperones to inhibit the formation of $A \beta(M 1-40)$ and $\beta 2 \mathrm{~m}$ fibrils. Hydrophobicity and hydrogen bonding between $A \beta(M 1-40)$ or $\beta 2 \mathrm{~m}$ and mannan nanogel, through their hydrophobic domains and polar groups of polymer backbone, respectively, may play a role in binding and/or preventing the nucleation and elongation of the fibrils. The present study was performed using pure $A \beta(M 1-40)$ or $\beta 2 \mathrm{~m}$ without competition from other proteins for binding to the nanoparticle surface, which are conditions dissimilar to those in vivo in terms of salts, metabolites and biological membranes, and unlike any realistic clinical situation. Still, systematic investigation in vitro of the aggregation process shows evidence of a retardation effect of mannan nanogel in fibrillation, an extraordinary hint of its biosafety and promising biomedical applicability.

\section{Conclusions}

The corona around nanogel is quite specific and simple, and contains a small number of proteins including apolipoproteins B-100, A-I and E, and HSA. The protein corona evolves over time and is formed through a slow process, and the equilibrium is reached only after ca. $24 \mathrm{~h}$. Interaction with the mannan nanogel leads to an increased or unchanged $\alpha$ helical structure for apoA-I and HSA, respectively. After binding of HSA to the nanogel, the environment around the tryptophan side chains is more hydrophobic. Moreover, blood coagulation is unperturbed and $A \beta(M 1-40)$ and $\beta 2 m$ fibrillation is retarded by mannan nanogel suggesting biosafety, which is mandatory for nanomaterials to be used in biomedical applications.

Supplementary related to this article can be found online at doi:10.1016/j.bbagen.2012.04.015.

\section{Acknowledgements}

The authors thank the financial support by International Iberian Nanotechnology Laboratory (INL), Fundação para a Ciência e a Tecnologia (FCT, Portugal), through PTDC, European Science Foundation (ESF) for the activity entitled 'Mapping the detailed composition of Surface-Absorbed Protein Layers on Biomaterials and Nanoparticles', the Crafoord Foundation, and Lund and Nano Vaccine Center, Denmark. The NIPAM coated gold particle is a kind gift from Colloidal Chemistry Group from Vigo University, Spain.

\section{References}

[1] A.V. Kabanov, S.V. Vinogradov, Nanogels as pharmaceutical carriers: finite networks of infinite capabilities, Angew. Chem. Int. Ed. 48 (2009) 5418-5429.

[2] J.K. Oh, Engineering of nanometer-sized cross-linked hydrogels for biomedical applications, Can. J. Chem. 88 (2010) 173-184.

[3] S.A. Ferreira, P. Pereira, P. Sampaio, P.J.G. Coutinho, F.M. Gama, Supramolecular assembled nanogel made of mannan, J. Colloid Interface Sci. 361 (2011) 97-108.

[4] V. Apostolopoulos, G.A. Pietersz, B.E. Loveland, M.S. Sandrin, I.F. McKenzie, Oxidative/reductive conjugation of mannan to antigen selects for T1 or T2 immune responses, Proc. Natl. Acad. Sci. U.S.A. 92 (1995) 10128-10132.

[5] X.G. Gu, M. Schmitt, A. Hiasa, Y. Nagata, H. Ikeda, Y. Sasaki, K. Akiyoshi, J. Sunamoto, H. Nakamura, K. Kuribayashi, H. Shiku, A novel hydrophobized polysaccharide/oncoprotein complex vaccine induces in vitro and in vivo cellular and humoral immune responses against HER2-expressing murine sarcomas, Cancer Res. 58 (1998) 3385-3390.
[6] V. Sihorkar, S.P. Vyas, Potential of polysaccharide anchored liposomes in drug delivery, targeting and immunization, J. Pharm. Pharm. Sci. 4 (2001) 138-158.

[7] A. Gupta, R.K. Gupta, G.S. Gupta, Targeting cells for drug and gene delivery: emerging applications of mannans and mannan binding lectins, J. Sci. Ind. Res. 68 (2009) 465-483.

[8] A. Avrameas, D. Mcllroy, A. Hosmalin, B. Autran, P. Debre, M. Monsigny, A.C. Roche, P. Midoux, Expression of a mannose/fucose membrane lectin on human dendritic cells, Eur. J. Immunol. 26 (1996) 394-400.

[9] M. Fukasawa, Y. Shimizu, K. Shikata, M. Nakata, R. Sakakibara, N. Yamamoto, M Hatanaka, T. Mizuochi, Liposome oligomannose-coated with neoglycolipid, a new candidate for a safe adjuvant for induction of CD8 + cytotoxic T lymphocytes, FEBS Lett. 441 (1998) 353-356.

[10] V. Apostolopoulos, I.F. McKenzie, Role of the mannose receptor in the immune response, Curr. Mol. Med. 1 (2001) 469-474.

[11] T. Cedervall, I. Lynch, M. Foy, T. Berggard, S.C. Donnelly, G. Cagney, S. Linse, K.A. Dawson, Detailed identification of plasma proteins adsorbed on copolymer nanoparticles, Angew. Chem. Int. Ed Engl. 46 (2007) 5754-5756.

[12] T. Cedervall, I. Lynch, S. Lindman, T. Berggård, E. Thulin, H. Nilsson, K.A. Dawson, S. Linse, Understanding the nanoparticle-protein corona using methods to quantify exchange rates and affinities of proteins for nanoparticles, Proc. Natl. Acad. Sci. U.S.A. 104 (2007) 2050-2055.

[13] E. Hellstrand, I. Lynch, A. Andersson, T. Drakenberg, B. Dahlbäck, K.A. Dawson, S Linse, T. Cedervall, Complete high-density lipoproteins in nanoparticle corona, FEBS J. 276 (2009) 3372-3381.

[14] P. Aggarwal, J.B. Hall, C.B. McLeland, M.A. Dobrovolskaia, S.E. McNeil, Nanoparticle interaction with plasma proteins as it relates to particle biodistribution, biocompatibility and therapeutic efficacy, Adv. Drug Deliv. Rev. 61 (2009) 428-437.

[15] M.P. Monopoli, D. Walczyk, A. Campbell, G. Elia, I. Lynch, F.B. Bombelli, K.A. Dawson, Physical-chemical aspects of protein corona: relevance to in vitro and in vivo biological impacts of nanoparticles, J. Am. Chem. Soc. 133 (2011) 2525-2534.

[16] M. Lundqvist, I. Sethson, B.-H. Jonsson, Protein adsorption onto silica nanoparticles: conformational changes depend on the particles' curvature and the protein stability, Langmuir 20 (2004) 10639-10647.

[17] X.R. Xia, N.A. Monteiro-Riviere, J.E. Riviere, An index for characterization of nanomaterials in biological systems, Nat. Nanotechnol. 5 (2010) 671-675.

[18] W. Shang, J.H. Nuffer, V.A. Muñiz-Papandrea, W. Colón, R.W. Siegel, J.S. Dordick Cytochrome c on silica nanoparticles: influence of nanoparticle size on protein structure, stability, and activity, Small 5 (2009) 470-476.

[19] P. Roach, D. Farrar, C.C. Perry, Surface tailoring for controlled protein adsorption: effect of topography at the nanometer scale and chemistry, J. Am. Chem. Soc. 128 (2006) 3939-3945.

[20] M. Lundqvist, J. Stigler, G. Elia, I. Lynch, T. Cedervall, K.A. Dawson, Nanoparticle size and surface properties determine the protein corona with possible implications for biological impacts, Proc. Natl. Acad. Sci. U.S.A. 105 (2008) 14265-14270.

[21] D. Dell'Orco, M. Lundqvist, C. Oslakovic, T. Cedervall, S. Linse, Modeling the time evolution of the nanoparticle-protein corona in a body fluid, PLoS One 5 (2010) e10949.

[22] E. Casals, T. Pfaller, A. Duschl, G.J. Oostingh, V. Puntes, Time evolution of the nanoparticle protein corona, ACS Nano 4 (2010) 3623-3632.

[23] D. Walczyk, F.B. Bombelli, M.P. Monopoli, I. Lynch, K.A. Dawson, What the cell "sees" in bionanoscience, J. Am. Chem. Soc. 132 (2010) 5761-5768.

[24] G. Maiorano, S. Sabella, B. Sorce, V. Brunetti, M.A. Malvindi, R. Cingolani, P.P. Pompa, Effects of cell culture media on the dynamic formation of protein-nanoparticle complexes and influence on the cellular response, ACS Nano 4 (2010) 7481-7491.

[25] M. Lundqvist, J. Stigler, T. Cedervall, T. Berggård, M.B. Flanagan, I. Lynch, G. Elia, K Dawson, The evolution of the protein corona around nanoparticles: a test study, ACS Nano 5 (2011) 7503-7509.

[26] S. Nagayama, K. Ogawara, Y. Fukuoka, K. Higaki, T. Kimura, Time-dependent changes in opsonin amount associated on nanoparticles alter their hepatic uptake characteristics, Int. J. Pharm. 342 (2007) 215-221.

[27] B.D. Chithrani, W.C.W. Chan, Elucidating the mechanism of cellular uptake and removal of protein-coated gold nanoparticles of different sizes and shapes, Nano Lett. 7 (2007) 1542-1550.

[28] G. Oberdörster, Safety assessment for nanotechnology and nanomedicine: concepts of nanotoxicology, J. Intern. Med. 267 (2010) 89-105.

[29] M.S. Ehrenberg, A.E. Friedman, J.N. Finkelstein, G. Oberdörster, J.L. McGrath, The influence of protein adsorption on nanoparticle association with cultured endothelial cells, Biomaterials 30 (2009) 603-610.

[30] I. Lynch, T. Cedervall, M. Lundqvist, C. Cabaleiro-Lago, S. Linse, K.A. Dawson, The nanoparticle-protein complex as a biological entity; a complex fluids and surface science challenge for the 21st century, Adv. Colloid Interface Sci. 134-135 (2007) 167-174.

[31] X. Jiang, S. Weise, M. Hafner, C. Rocker, F. Zhang, W.J. Parak, G.U. Nienhaus, Quantitative analysis of the protein corona on FePt nanoparticles formed by transferrin binding, J. R. Soc. Interface 7 (Suppl. 1) (2010) S5-S13.

[32] A. Lesniak, A. Campbell, M.P. Monopoli, I. Lynch, A. Salvati, K.A. Dawson, Serum heat inactivation affects protein corona composition and nanoparticle uptake, Biomaterials 31 (2010) 9511-9518.

[33] M.A. Dobrovolskaia, P. Aggarwal, J.B. Hall, S.E. McNeil, Preclinical studies to understand nanoparticle interaction with the immune system and its potential effects on nanoparticle biodistribution, Mol. Pharm. 5 (2008) 487-495.

[34] I. Lynch, K.A. Dawson, Protein-nanoparticle interactions, Nano Today 3 (2008) 40-47. 
[35] T.A. Faunce, J. White, K.I. Matthaei, Integrated research into the nanoparticle-protein corona: a new focus for safe, sustainable and equitable development of nanomedicines, Nanomedicine (Lond.) 3 (2008) 859-866.

[36] I. Fenoglio, B. Fubini, E. Ghibaudi, F. Turci, Multiple aspects of the interaction of biomacromolecules with inorganic surfaces, Adv. Drug Deliv. Rev. 63 (2011) 1186-1209.

[37] Z.J. Deng, M. Liang, M. Monteiro, I. Toth, R.F. Minchin, Nanoparticle-induced unfolding of fibrinogen promotes Mac-1 receptor activation and inflammation, Nat. Nanotechnol. 6 (2010) 39-44.

[38] J. Kim, J.W. Grate, P. Wang, Nanostructures for enzyme stabilization, Chem. Eng. Sci. 61 (2006) 1017-1026

[39] S. Koutsopoulos, K. Patzsch, W.T.E. Bosker, W. Norde, Adsorption of trypsin on hydrophilic and hydrophobic surfaces, Langmuir 23 (2007) 2000-2006.

[40] J.E. Gagner, M.D. Lopez, J.S. Dordick, R.W. Siegel, Effect of gold nanoparticle morphology on adsorbed protein structure and function, Biomaterials 32 (2011) 7241-7252.

[41] R. Cukalevski, M. Lundqvist, C. Oslakovic, B. Dahlbäck, S. Linse, T. Cedervall, Structural changes in apolipoproteins bound to nanoparticles, Langmuir 27 (2011) 14360-14269.

[42] T. Cedervall, L.-A. Hansson, M. Lard, B. Frohm, S. Linse, Food chain transport of nanoparticles affects behaviour and fat metabolism in fish, PLoS One 7 (2012) e32254.

[43] C. Oslakovic, T. Cedervall, S. Linse, B. Dahlbäck, Polystyrene nanoparticles affecting blood coagulation, Nanomedicine (2011), http://dx.doi.org/10.1016/j.nano.2011.12. 001.

[44] J. Laloy, S. Robert, C. Marbehant, F. Mullier, J. Mejia, J.P. Piret, S. Lucas, B. Chatelain J.M. Dogne, O. Toussaint, B. Masereel, S. Rolin, Validation of the calibrated thrombin generation test (cTGT) as the reference assay to evaluate the procoagulant activity of nanomaterials, Nanotoxicology 6 (2012) 213-232.

[45] L. Fei, S. Perrett, Effect of nanoparticles on protein folding and fibrillogenesis, Int. J. Mol. Sci. 10 (2009) 646-655.

[46] D. Brambilla, B. Le Droumaguet, J. Nicolas, S.H. Hashemi, L.-P. Wu, S.M. Moghimi, P. Couvreur, K. Andrieux, Nanotechnologies for Alzheimer's disease: diagnosis, therapy, and safety issues, Nanomedicine 7 (2011) 521-540.

[47] J.P. Cleary, D.M. Walsh, J.J. Hofmeister, G.M. Shankar, M.A. Kuskowski, D.J. Selkoe K.H. Ashe, Natural oligomers of the amyloid- $\beta$ protein specifically disrupt cognitive function, Nat. Neurosci. 8 (2005) 79-84.

[48] S. Baglioni, F. Casamenti, M. Bucciantini, L.M. Luheshi, N. Taddei, F. Chiti, C.M. Dobson, M. Stefani, Prefibrillar amyloid aggregates could be generic toxins in higher organisms, J. Neurosci. 26 (2006) 8160-8167.

[49] K. Ikeda, T. Okada, S.-i. Sawada, K. Akiyoshi, K. Matsuzaki, Inhibition of the formation of amyloid $\beta$-protein fibrils using biocompatible nanogels as artificial chaperones, FEBS Lett. 580 (2006) 6587-6595.

[50] C. Cabaleiro-Lago, F. Quinlan-Pluck, I. Lynch, S. Lindman, A.M. Minogue, E. Thulin D.M. Walsh, K.A. Dawson, S. Linse, Inhibition of amyloid $\beta$ protein fibrillation by polymeric nanoparticles, J. Am. Chem. Soc. 130 (2008) 15437-15443.
[51] S. Linse, C. Cabaleiro-Lago, W.-F. Xue, I. Lynch, S. Lindman, E. Thulin, S.E. Radford, K.A. Dawson, Nucleation of protein fibrillation by nanoparticles, Proc. Natl. Acad. Sci. U.S.A. 104 (2007) 8691-8696.

[52] C. Cabaleiro-Lago, F. Quinlan-Pluck, I. Lynch, K.A. Dawson, S. Linse, Dual effect of amino modified polystyrene nanoparticles on amyloid $\beta$ protein fibrillation, ACS Chem. Neurosci. 1 (2010) 279-287.

[53] C. Oslakovic, M.J. Krisinger, A. Andersson, M. Jauhiainen, C. Ehnholm, B. Dahlback, Anionic phospholipids lose their procoagulant properties when incorporated into high density lipoproteins, J. Biol. Chem. 284 (2009) 5896-5904.

[54] D.M. Walsh, E. Thulin, A.M. Minogue, N. Gustavsson, E. Pang, D.B. Teplow, S. Linse, A facile method for expression and purification of the Alzheimer's diseaseassociated amyloid beta-peptide, FEBS J. 276 (2009) 1266-1281.

[55] M.J. Krisinger, L.J. Guo, G.L. Salvagno, G.C. Guidi, G. Lippi, B. Dahlback, Mouse recombinant protein $\mathrm{c}$ variants with enhanced membrane affinity and hyperanticoagulant activity in mouse plasma, FEBS J. 276 (2009) 6586-6602.

[56] H. LeVine 3rd, Thioflavine T interaction with synthetic Alzheimer's disease $\beta$ amyloid peptides: detection of amyloid aggregation in solution, Protein Sci. 2 (1993) 404-410.

[57] H. Naiki, F. Gejyo, Kinetic analysis of amyloid fibril formation, Methods Enzymol. 309 (1999) 305-318.

[58] H. Levine, Thioflavin-T interaction with amyloid beta-sheet structures, Amyloid 2 (1995) 1-6.

[59] F. Chiti, C.M. Dobson, Protein misfolding, functional amyloid, and human disease, Annu. Rev. Biochem. 75 (2006) 333-366.

[60] J.T. Jarrett, P.T. Lansbury, Amyloid fibril formation requires a chemically discriminating nucleation event: studies of an amyloidogenic sequence from the bacterial protein OsmB, Biochemistry 31 (1992) 12345-12352.

[61] M. Safi, J. Courtois, M. Seigneuret, H. Conjeaud, J.F. Berret, The effects of aggregation and protein corona on the cellular internalization of iron oxide nanoparticles, Biomaterials 32 (2011) 9353-9363.

[62] S.H.D.P. Lacerda, J.J. Park, C. Meuse, D. Pristinski, M.L. Becker, A. Karim, J.F. Douglas, Interaction of gold nanoparticles with common human blood proteins, ACS Nano 4 (2009) 365-379.

[63] H. Saito, P. Dhanasekaran, D. Nguyen, E. Deridder, P. Holvoet, S. Lund-Katz, M.C. Phillips, $\alpha$-helix formation is required for high affinity binding of human apolipoprotein A-I to lipids, J. Biol. Chem. 279 (2004) 20974-20981.

[64] Y. Fang, O. Gursky, D. Atkinson, Lipid-binding studies of human apolipoprotein AI and its terminally truncated mutants, Biochemistry 42 (2003) 13260-13268.

[65] M. Kono, Y. Okumura, M. Tanaka, D. Nguyen, P. Dhanasekaran, S. Lund-Katz, M.C. Phillips, H. Saito, Conformational flexibility of the N-terminal domain of apolipoprotein A-I bound to spherical lipid particles, Biochemistry 47 (2008) $11340-11347$.

[66] S. Lindman, I. Lynch, E. Thulin, H. Nilsson, K.A. Dawson, S. Linse, Systematic investigation of the thermodynamics of HSA adsorption to $\mathrm{N}$-iso-propylacrylamide/ $\mathrm{N}$ tert-butylacrylamide copolymer nanoparticles. Effects of particle size and hydrophobicity, Nano Lett. 7 (2007) 914-920. 